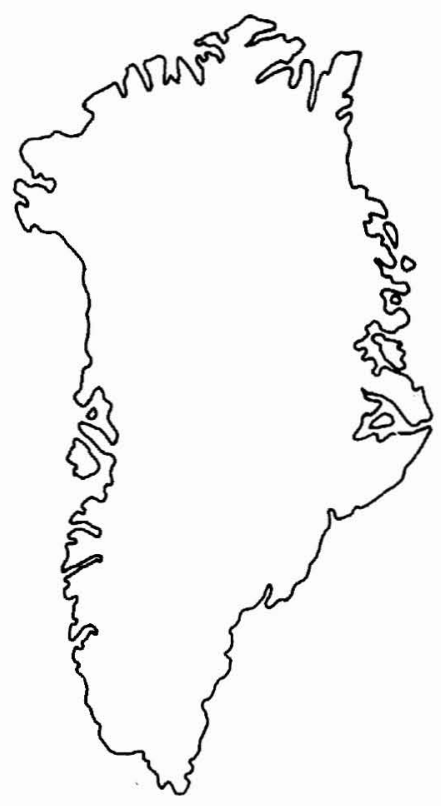

\title{
The Morris Bugt Group (Middle Ordovician - Silurian) of North Greenland and its correlatives
}

\author{
M. Paul Smith, Martin Sønderholm and Simon J. Tull
}

The Morris Bugt Group, originally proposed in western North Greenland, is now extended across the whole of North Greenland. One new formation, the Kap Jackson Formation, is described; it includes two members, the Gonioceras Bay and Troedsson Cliff Members, which correspond to earlier formations of the same names. In the Washington Land - western Peary Land region the group comprises the Kap Jackšon, Cape Calhoun and Aleqatsiaq Fjord Formations. The Børglum River and Tures $\emptyset$ Formations of the Peary Land - Kronprins Christian Land region are here added to the group. New data on the age of the formations based on conodont biostratigraphy are given, and correlations with Arctic Canada, East Greenland and Svalbard are discussed.

M. P. S., Department of Earth Sciences, University of Cambridge, Downing Street, Cambridge CB2 3EQ, England. Present address: Geologisk Museum, Øster Voldgade 5-7, DK-1350 København K, Denmark.

M. S., Grønlands Geologiske Undersøgelse, Øster Voldgade 10, DK-1350 København $K$, Denmark.

S. J. T., Department of Geology, University of Nottingham, University Park, Nottingham NG7 2RD, England. Present address: Chapman \& Hall, 11 New Fetter Lane, London EC4P 4EE, England.

The Morris Bugt Group was erected by Peel \& Hurst (1980) to encompass the Gonioceras Bay, Troedsson Cliff, Cape Calhoun and Aleqatsiaq Fjord Formations. These formations were originally described from Washington Land (Troedsson, 1926, 1928; Koch, 1929a,b; Hurst, 1980) but had also been recognised farther to the east in the Hall Land - Wulff Land region (Hurst \& Peel, 1979; Dawes \& Peel, 1984) (figs 1, 2). The Børglum River Formation in the Peary Land - Kronprins Christian Land region was recognised to be a correlative of the Morris Bugt Group (Peel, 1982), but was not included in the group in the absence of data from the intermediate areas. During 1984 and 1985 the Morris Bugt Group was mapped in the Washington Land Freuchen Land area in conjunction with an extensive conodont sampling programme. Following this, it became evident that the group could be extended farther eastwards into the Peary Land - Kronprins Christian Land region. The original division of the lower part of the group into the Gonioceras Bay and Troedsson Cliff Formations was, however, difficult to recognise in some areas, and these two formations are here treated as members of a new unit, the Kap Jackson Formation. The Aleqatsiaq Fjord Formation is subdivided into three members by Sønderholm \& Harland (in prep.) who give full formal descriptions of these members. The lower member of the Aleqatsiaq Fjord Formation correlates with the upper part of the Børglum River Formation. The upper two members of the Aleqatsiaq Fjord Formation show a gradual west-east change in lithological characteristics, and in western Peary Land grade into the Tures $\varnothing$ Formation of Hurst (1984). As a consequence of this, the Tures $\emptyset$ Formation is included in the extended Morris Bugt Group, despite the differences in depositional environment of the two formations.

\section{Geological setting}

The sediments of the Morris Bugt Group formed on a broad, stable carbonate platform fringing the southern margin of the Franklinian Basin in North Greenland (fig. 1). This stable platform, recognised as stage 5 in the evolution of the Franklinian Basin (Higgins et al., in press), evolved as a consequence of a regional eustatic transgression during late Middle Ordovician time (Fortey, 1984) which affected shelf areas in the Canadian Arctic Archipelago and North Greenland. Formations of this stage can easily be correlated throughout the 


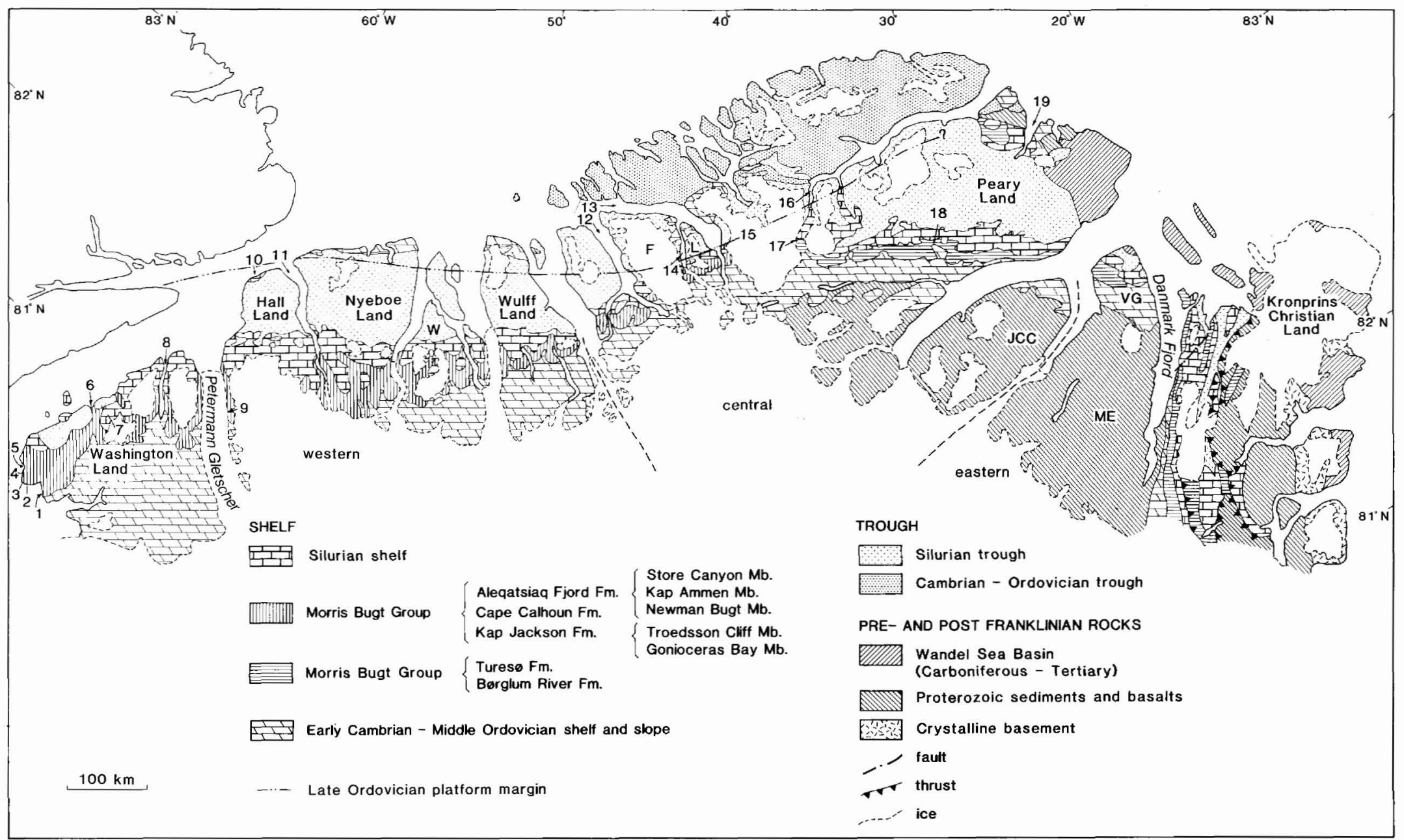

Fig. 1. Simplified geological map of North Greenland, with place names used in the text. F: Freuchen Land; JCC: J. C. Christensen Land; L: Lauge Koch Land; ME: Mylius-Erichsen Land; VG: Valdemar Glückstadt Land; W: Warming Land. 1: Gonioceras Bugt; 2: Troedsson Klipper; 3: Kap Jackson; 4: Kap Calhoun; 5: Morris Bugt; 6: Aleqatsiaq Fjord; 7: Pentamerus Bjerge; 8: Bessels Fjord; 9: Kap Eisendecher; 10: Kap Ammen; 11: Newman Bugt; 12: Nordenskiöld Fjord; 13: J. P. Koch Fjord; 14: Navarana Fjord; 15: Hans Tavsen Iskappe; 16: Odin Fjord; 17: Turesø; 18: Børglum Elv; 19: G. B. Schley Fjord. 
Franklinian Basin (Christie \& Peel, 1977; Peel \& Christie, 1982). The generally dark, monotonously developed limestones of quiet, relatively deep water, open marine aspect referred to the Morris Bugt Group everywhere overlie pale, restricted shallow water carbonates which are locally evaporitic and referred to the Ryder Gletscher Group (fig. 2). The carbonate platform margin to the north (fig. 1) was a scarp-like feature, the Navarana Fjord Escarpment (fig. 1), and separated the platform from a broad slope, which only received very small amounts of sediment. In the deep water trough north of the escarpment, sediments are dominated by mud and silicious ooze interlayered with turbidites and carbonate conglomerates (Higgins et al., in press).

\section{Morris Bugt Group}

revised

History. The Morris Bugt Group was established by Peel \& Hurst (1980) to include the Gonioceras Bay, Troedsson Cliff, Cape Calhoun and Aleqatsiaq Fjord Formations in western North Greenland. The Børglum River and Tures $\varnothing$ Formations of central and eastern North Greenland, described by Christie \& Peel (1977) and Hurst (1984), are added to the group. The 'dark weathering limestone and dolomite unit' of Christie \& Ineson (1979) represents the group in the area around G. B. Schley Fjord, eastern Peary Land.

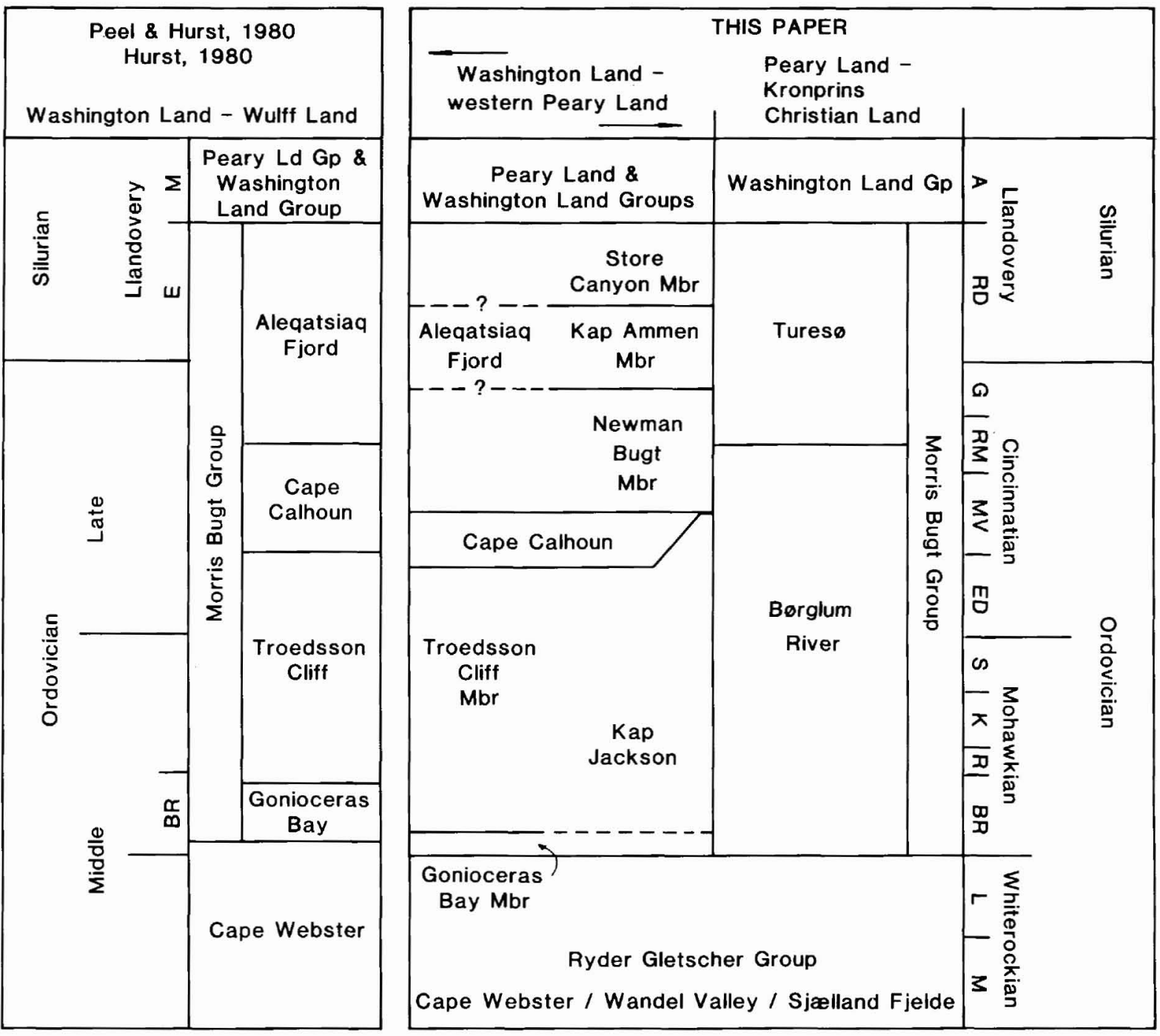

Fig. 2. Stratigraphic correlation scheme for the Morris Bugt Group of North Greenland. A: Aeronian; BR: Black Riveran; ED: Edenian; G: Gamachian; K: Kirkfieldian; MV: Maysvillian; R: Rocklandian; RD: Rhuddanian; RM: Richmondian; S: Shermanian; E: Early; M: Middle; L: Late. 
Name. After the bay, Morris Bugt, on the west coast of Washington Land (fig. 1).

Type area. The coastal cliffs around Morris Bugt.

Thickness. In Washington Land the group attains thicknesses between 700 and $760 \mathrm{~m}$ (Hurst, 1980; Peel \& Hurst, 1980). East of Washington Land thicknesses vary between $480 \mathrm{~m}$ and $580 \mathrm{~m}$. In Kronprins Christian Land a minimum thickness of approximately $600 \mathrm{~m}$ has been reported (Peel, 1985).
Dominant lithology. The group is predominantly composed of dark weathering, cliff-forming, grey-brown mottled, dolomitic skeletal limestones (Kap Jackson, Aleqatsiaq Fjord and Børglum River Formations). In the middle of the group in the Washington Land Lauge Koch Land area is a recessive unit, the Cape Calhoun Formation, which comprises greenish weathering silty limestones. In the Peary Land - Kronprins Christian Land region, the top of the group is composed of medium- to thick-bedded, grey weathering dolomites and limy dolomites, the Turesø Formation.
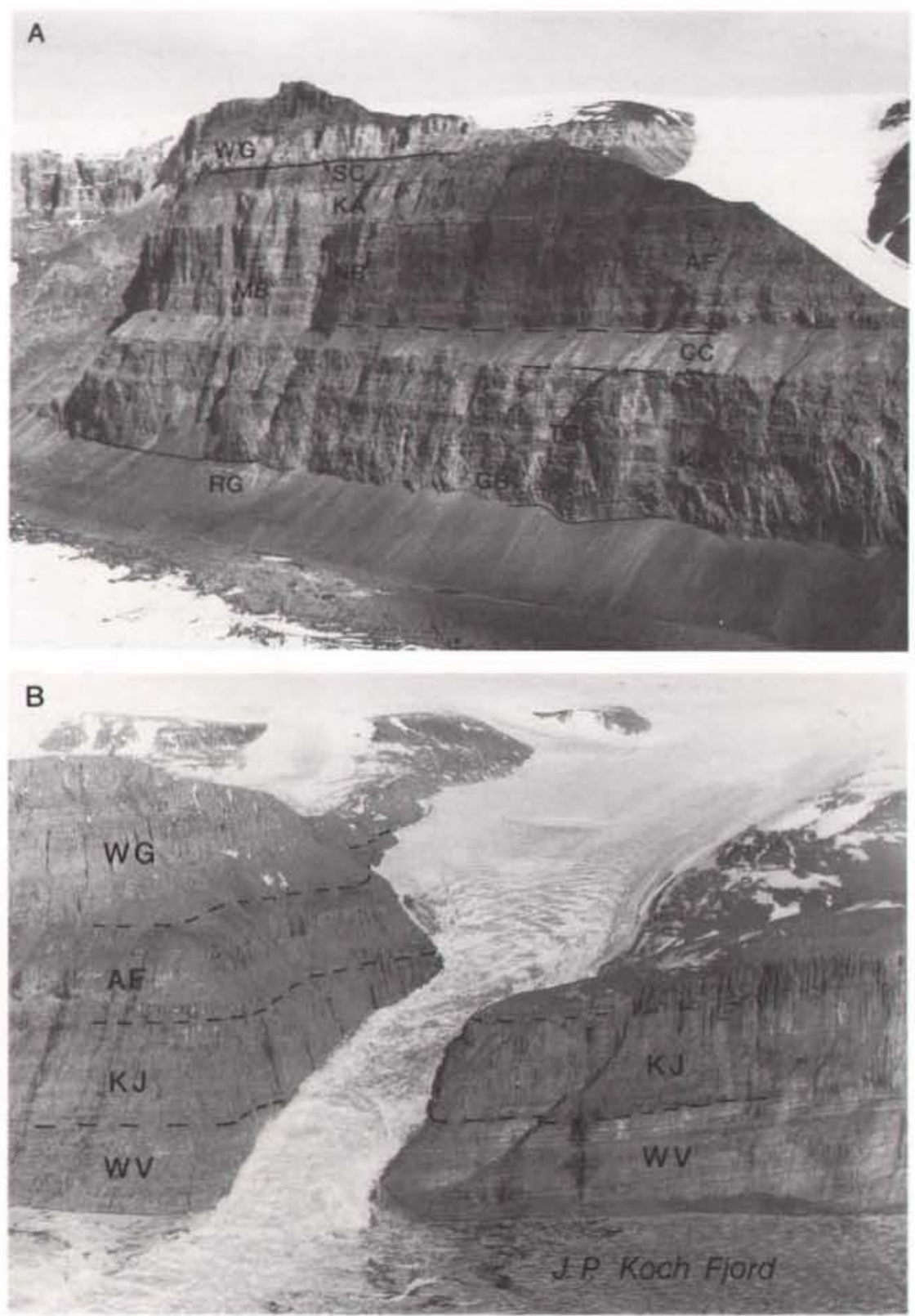

Fig. 3, A: The Morris Bugt Group (MB) at Kap Eisendecher, western coast of Hall Land. AF: Aleqatsiaq Fjord Formation; CC: Cape Calhoun Formation; GB: Gonioceras Bay Member; KA: Kap Ammen Member; KJ: Kap Jackson Formation: NB: Newman Bugt Member; RG: Ryder Gletscher Group; SC: Store Canyon Member: TC: Troedsson Cliff Member: WG: Washington Land Group. Height of cliff approximately $900 \mathrm{~m}$.

B: Aleqatsiaq Fjord Formation at its easternmost outcrop in the west-facing cliffs of J. P. Koch Fjord. AF: Aleqatsiaq Fjord Formation; KJ: Kap Jackson Formation: WG: Washington Land Group WV: Wandel Valley Formation. Height of cliffs left of glacier, approximately $850 \mathrm{~m}$. 
Boundaries. The group rests conformably upon the Cape Webster Formation throughout the Washington Land - western Freuchen Land area. In the Lauge Koch Land - Peary Land region it conformably overlies the Vestervig Elv Member of the Wandel Valley Formation (Sønderholm \& Due, 1985; Peel \& Smith, 1988) whilst in Valdemar Glückstadt Land and Kronprins Christian Land the group rests conformably upon the Sjælland Fjelde Formation (Ineson et al., 1986). In general, the Morris Bugt Group is overlain by the Washington Land Group. However, the Peary Land Group (Hurst \& Surlyk, 1982) overlies the group in the north-western part of Washington Land (Hurst, 1980) and is also in depositional contact with it along the Navarana Fjord Escarpment (Surlyk et al., 1980; Escher \& Larsen, 1987).

Distribution. The Morris Bugt Group forms a characteristic, major, dark weathering and cliff-forming unit across North Greenland above the pale, recessive weathering Cape Webster and Wandel Valley Formations. In western Washington Land it is overlain by the dark, recessive Cape Schuchert Formation (Peary Land Group) (Hurst, 1980) whereas further to the east it is succeeded by the pale Petermann Halvø and Ymers Gletscher Formations (Washington Land Group) (fig. 3). In Kronprins Christian Land the dolomitic Turesø Formation is followed by the dark, cliff-forming limestones of the Odins Fjord Formation (Washington Land Group) (Sønderholm \& Harland, in prep.) (fig. 9).

Biota and age. The group contains a rich and diverse macrofauna but these faunas are much in need of taxonomic revision and consequently are of limited biostratigraphic utility at present. Palynological investigations (Nøhr-Hansen, 1989) have revealed various floral and faunal components (acritarchs, chitinozoans, scolecodonts, trilete spores and graptolite fragments). Conodonts are generally abundant and diverse, and are the principal biostratigraphic indicators employed. They are of North American Midcontinent affinity and allow direct correlation with the conodont zones erected by Sweet (1984). These were originally defined as chronozones using graphic correlation but are here treated as first-occurrence biozones. The base of the group is of early Black Riveran (Mohawkian, Middle Ordovician) age and the top is early Llandovery (Early Silurian). Diachronism cannot be detected at either the base or the top of the group. Further details are given below in the description of the constituent units.

Subdivisions. Between Washington Land and Nares Land, the Morris Bugt Group is divided into three formations; the Kap Jackson Formation (new) which may be divided into the Gonioceras Bay and Troedsson Cliff Members (formerly formations), the Cape Calhoun Formation and the Aleqatsiaq Fjord Formation, which is divided into the Newman Bugt, Kap Ammen and Store Canyon Members (Sønderholm \& Harland, in prep.). The Cape Calhoun Formation thins eastwards and wedges out in the region of Nordenskiöld Fjord; in Freuchen Land and western Peary Land the Aleqatsiaq Fjord Formation rests directly on the Kap Jackson Formation. East of Hans Tavsen Iskappe as far as Kronprins Christian Land the group is divided into two formations; the Børglum River and Turesø Formations.

\section{Kap Jackson Formation}

new

History. Field work during 1984 showed that the original subdivision of the lower part of the Morris Bugt Group into the Gonioceras Bay and Troedsson Cliff Formations as suggested by Peel \& Hurst (1980) is not practical at all localities. The two formations are therefore combined into a single unit, the Kap Jackson Formation, and the previously recognised divisions are treated as members. The formation corresponds in part to unit 14A of Dawes \& Peel (1984).

Name. From Kap Jackson on the west coast of Washington Land (fig. 1).

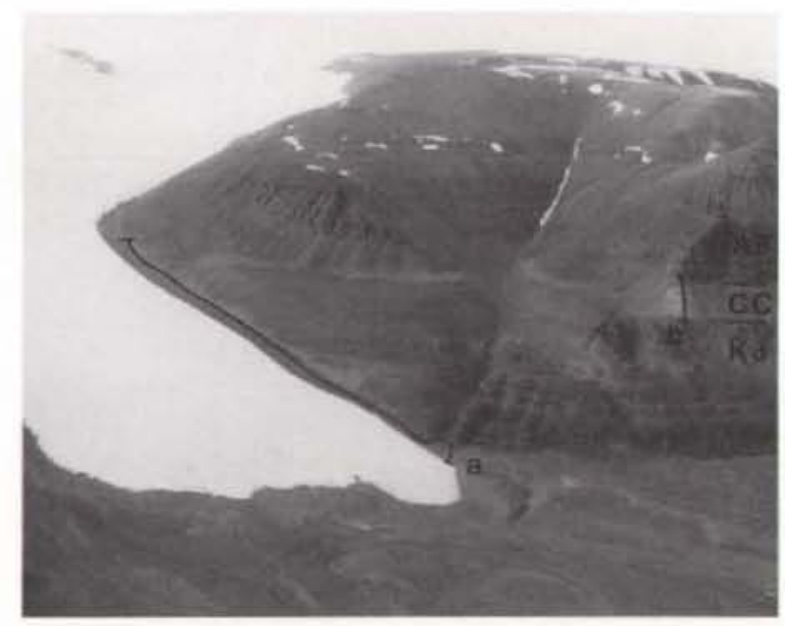

Fig. 4. Oblique aerial view of the reference section of the Kap Jackson Formation (a: MPS 840810-1) and the Cape Calhoun Formation (b: MPS 840813-1) at the southern end of Bessels Fjord on the western side. Thickness of Cape Calhoun Formation is $60 \mathrm{~m}$. Formation abbreviations as for fig. 3 . 
Type and reference sections. The type section is at Gonioceras Bugt and there is a reference section at the southern end of Bessels Fjord (figs 1, 4).

Thickness. Measured thicknesses show a thinning from $230 \mathrm{~m}$ at Bessels Fjord in the west to $170 \mathrm{~m}$ in Wulff Land in the east.

Lithology. In general, the formation comprises dark, rubbly weathering, brown-grey, silty dolomitic wackestones and packstones with occasional grainstones, and has a nodular and burrow-mottled appearance (fig. 5). At the base, the formation is massive, brown weathering, porcellaneous and lacks burrow-mottling (Gonioceras Bay Member). Several of the bedding surfaces in the upper part of the Troedsson Cliff Member are irregular and iron stained, with abundant faunas, and are of possible hardground origin.

Biota and age. A rich and diverse macrofauna has been described from the formation (Troedsson, 1926, 1928; Koch, 1929b; Teichert, 1937; Troelsen, 1950; Dawes \& Peel, 1984),

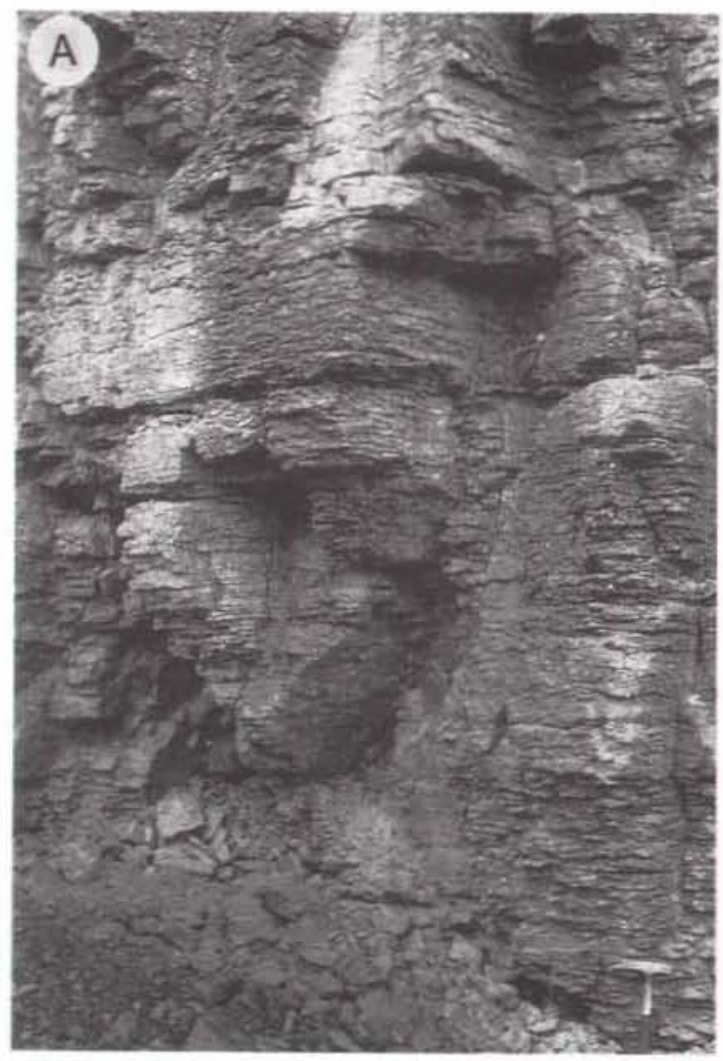

Conodont faunas indicate that the formation ranges from the lower $P$. aculeata Zone (early Black Riveran) to the $O$. velicuspis Zone (late Edenian) in the zonal scheme of Sweet (1984). Palynomorphs are common, and the upper part of the formation has yielded trilete spores (Nøhr-Hansen \& Koppelhus, 1988; Grahn \& Nøhr-Hansen, 1989). For details, see under individual members.

Boundaries. The boundary between the Ryder Gletscher Group and the Kap Jackson Formation is generally very sharp and is defined by the change from pale, recessive weathering dolomites to dark, strongly cliff-forming limestones (figs 3, 9). In Bessels Fjord, however, the boundary is more gradational, since the uppermost part of the Cape Webster Formation comprises interbedded pale laminated micrites and dark burrow-mottled micrites. The boundary is placed at the top of the highest pale bed. In Nares Land the lower 13 $\mathrm{m}$ of the Kap Jackson Formation consists of grey, thin to medium-bedded limestones (Sønderholm \& Due, 1985).

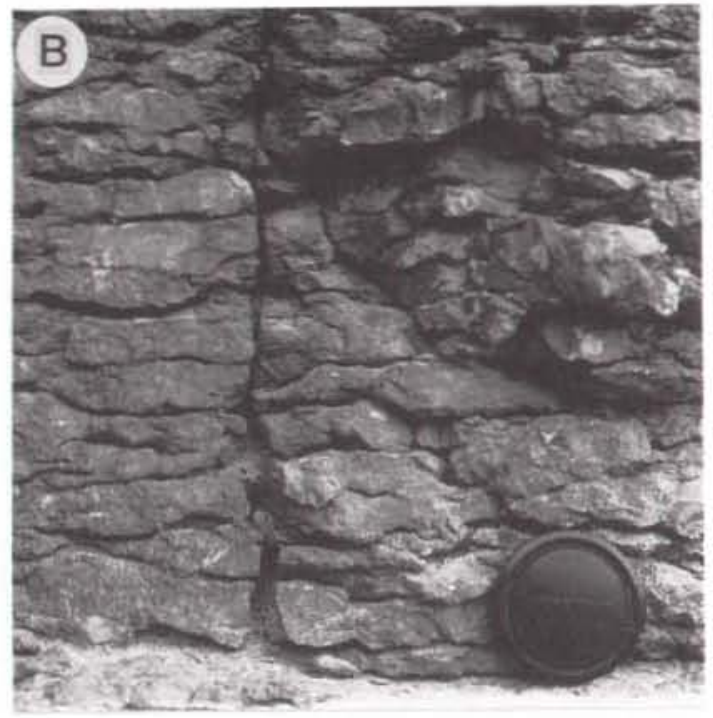

Fig. 5. Typically cliff-forming, burrow mottled limestones of the Kap Jackson Formation (A). Close-up of lithology (B). Bessels Fjord. 
The boundary between the Kap Jackson Formation and the overlying Cape Calhoun Formation is gradational and is characterised by a change from dark grey, medium- to thick-bedded limestones to thinner bedded, strongly recessive, rubbly weathering limestones with abundant pale green silty partings. East of Nordenskiöld Fjord, the Cape Calhoun Formation wedges out (fig. 3B) and the rather recessive upper part of the Kap Jackson Formation is overlain by the massive beds of the lower Aleqatsiaq Fjord Formation.

Distribution. The formation can be followed as a mainly cliff-forming, dark weathering unit from Morris Bugt in western Washington Land to J. P. Koch Fjord. Around Hans Tavsen Iskappe it grades into the Børglum River Formation (fig. 1).

Subdivision. On the basis of bedding characteristics the formation may be split at most localities into two members, the Gonioceras Bay and Troedsson Cliff Members, which correspond to the original formations redefined by Peel \& Hurst (1980).

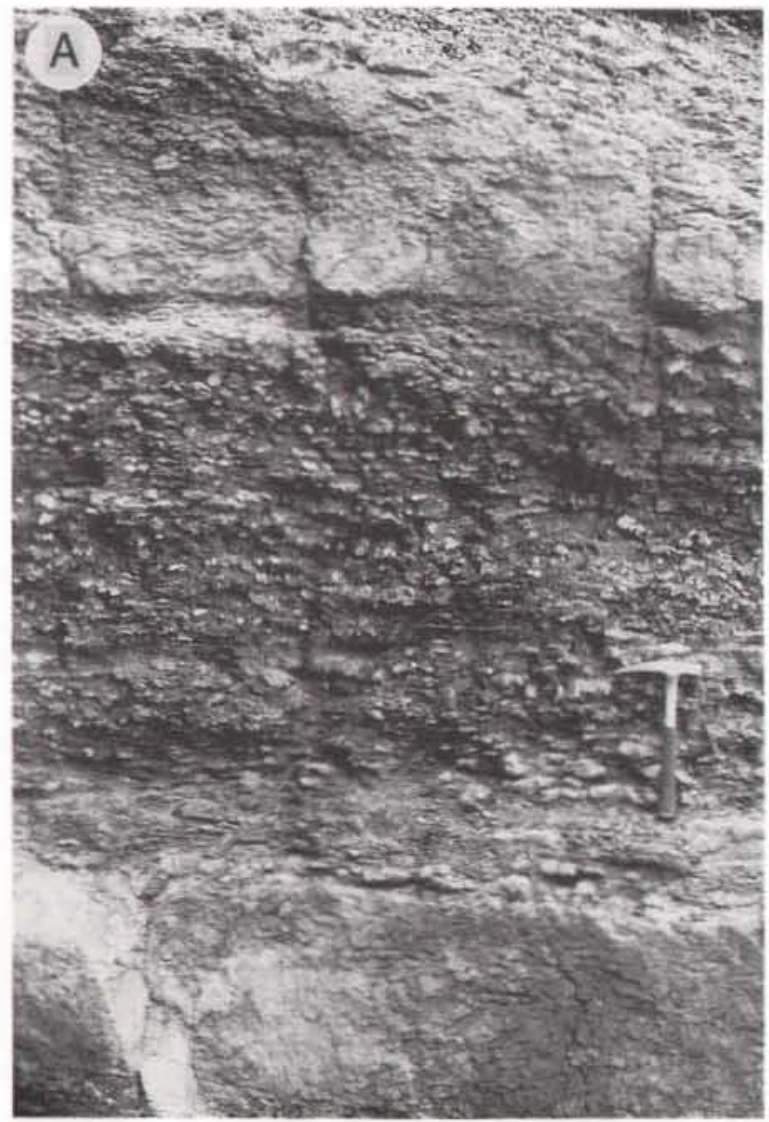

\section{Gonioceras Bay Member}

General. This member corresponds to the formation of the same name erected by Troedsson (1926) and redefined by Peel \& Hurst (1980), where additional information concerning the member may be found.

Type and reference sections. The type locality is at Gonioceras Bugt (fig. 1). A reference section is situated at the southern end of Bessels Fjord on the western side (fig. 4).

Thickness. In the area of the type locality the formation is $47 \mathrm{~m}$ thick (J. S. Peel, personal communication, 1987) which is significantly less than the $60-70 \mathrm{~m}$ noted by Peel \& Hurst (1980). The thickness decreases slightly towards the east to $36 \mathrm{~m}$ in eastern Wulff Land.

Biota and age. Conodont faunas are moderately diverse and abundant. Species present include Ansella robusta (Ethington \& Clark), Appalachignathus delicatulus Bergström et al., Drepanoistodus suberectus (Branson

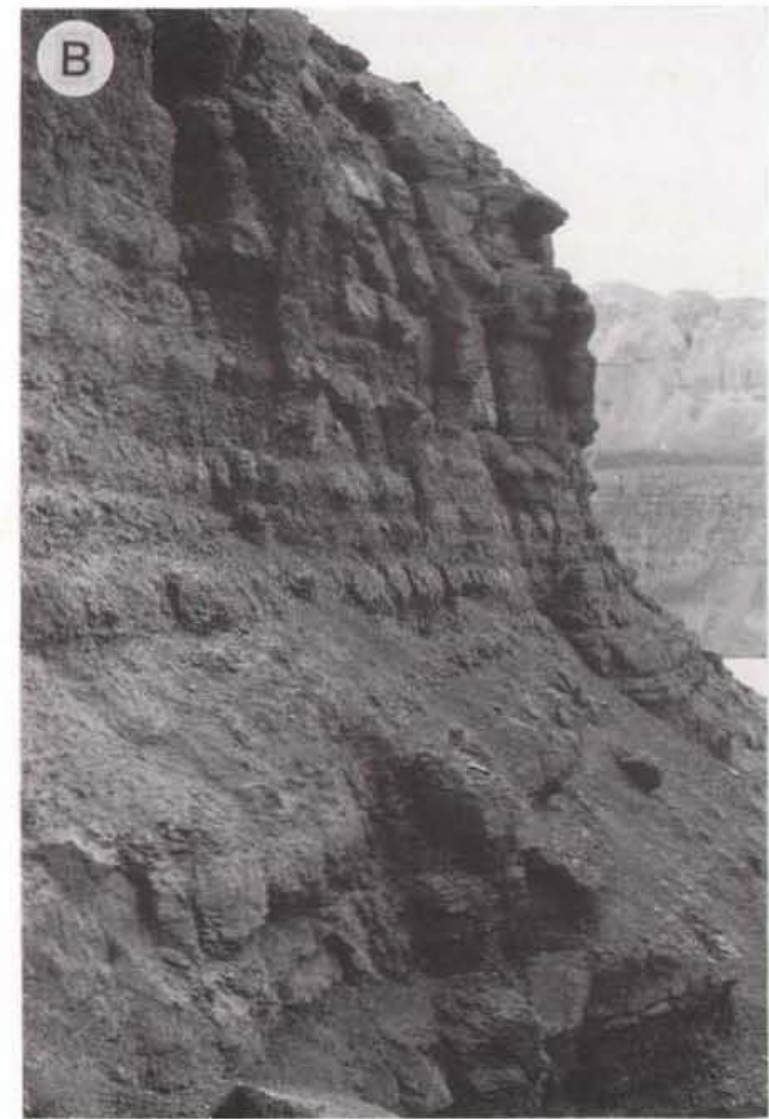

Fig. 6. Cape Calhoun Formation showing the typical nodular limestones with shaly partings (A), giving rise to a strongly recessive cliff-face (B). Section shown in (B) is approximately $15 \mathrm{~m}$ thick. Bessels Fjord. 
\& Mehl), Panderodus gracilis gracilis (Branson \& Mehl), Periodon aculeatus Hadding and a new species of Oulodus.

Although Peel \& Smith (1988) suggested that the base of the Morris Bugt Group, and hence this member, was of $C$. friendsvillensis Zone age, data from the more intensive sampling of the 1984 and 1985 field seasons indicate a slightly younger age. The short-ranging species Eoplacognathus elongatus (Bergström) is present at $12 \mathrm{~m}$ above the member base in Wulff Land and at $3 \mathrm{~m}$ in Nares Land, $25 \mathrm{~km}$ to the east. The species is best known from North Atlantic Province areas and Bergström $(1971,1983)$ recorded its first appearance as uppermost $A$. inaequalis Zone, equivalent to the uppermost $C$. sweeti Zone in the Midcontinent zonation (Sweet, 1984). In North America the species does not appear until just above the base of the Black Riveran Stage, in the lowest part of the $P$. aculeata Zone (Sweet, 1984; Bergstrōm et al., 1988). E. elongatus continues through into the overlying Troedsson Cliff Member at Bessels Fjord, indicating that the Gonioceras Bay Member is restricted to the basal part of the $P$. aculeata Zone and the lowermost Black Riveran.

Distribution. The member can be recognised at most localities in western North Greenland but it becomes increasingly difficult to differentiate eastwards. It cannot be unequivocally identified east of Freuchen Land.

\section{Troedsson Cliff Member}

Type and reference sections. The type locality is the coast between Morris Bugt and Kap Calhoun (fig. 1) (Koch, 1929a). A reference section is located at the southern end of Bessels Fjord on the western side (fig. 4), at the same locality as that for the Gonioceras Bay Member.

Thickness. In the area around Morris Bugt (fig. 1) a thickness of $240-250 \mathrm{~m}$ has been measured (J. S. Peel, personal communication, 1987). In Bessels Fjord the member is $186 \mathrm{~m}$ thick and the thickness steadily decreases to $135 \mathrm{~m}$ in eastern Wulff Land.

Biota and age. At Bessels Fjord, E. elongatus occurs up to $27 \mathrm{~m}$ above the base of the member denoting an earliest $P$. aculeata Zone (lowermost Black Riveran) age. The upper $30-35 \mathrm{~m}$ of the Troedsson Cliff Member is characterised by the appearance of the characteristic 'Red River' fauna which elsewhere is introduced in the upper part of the B. confluens Zone or the overlying $O$. velicuspis Zone (Sweet \& Bergström, 1984). Faunas are dominated by panderodontids, including species of $\mathrm{Be}$ - lodina, Culumbodina, Panderodus s.l. and Pseudobelodina s.I. At Bessels Fjord, Culumbodina occidentalis Sweet is introduced $19 \mathrm{~m}$ below the top of the member and ranges into the Cape Calhoun Formation. The range of this species is restricted to the $O$. velicuspis Zone (Sweet, 1984), within which the boundary between the Kap Jackson and Cape Calhoun Formations can be placed. In Wulff Land, the co-occurrence of $C$. occidentalis and Plegagnathus nelsoni Ethington \& Furnish in samples crossing the boundary further constrains the age to the uppermost Edenian - Maysvillian part of the zone.

\section{Cape Calhoun Formation}

History. The history of the Cape Calhoun Formation was reviewed by Peel \& Hurst (1980).

Name. From Kap Calhoun, south-western Washington Land (fig. 1).

Type and reference sections. The type area of the formation is around Kap Calhoun. A reference section which was extensively sampled for conodonts has been measured in southern Bessels Fjord (fig. 4).

Thickness. The formation thins from $60 \mathrm{~m}$ at Bessels Fjord to $40 \mathrm{~m}$ in Nyeboe Land and $30 \mathrm{~m}$ in Wulff Land. East of Nordenskiōld Fjord the formation wedges out, and in the environs of J. P. Koch Fjord it is seen only as a scarcely discernible horizon in the steep cliffs (fig. 3B).

Lithology. The formation is a rather uniform, strongly recessive unit composed of grey-green limestones with abundant pale green silty partings (fig. 6). The weathering appearance becomes more rubbly with increasing silt content. The unit is rather differently developed in Nyeboe Land where it is more nodular and shaly.

Biota and age. The formation has yielded a rich and diverse invertebrate fauna (Troedsson, 1926, 1928; Paul. 1979) and palynomorphs are common (Nøhr-Hansen. 1989). The Red River fauna documented by Sweet \& Bergström (1984) reaches its acme in the Cape Calhoun Formation with the domination of panderodontids reflecting the radiation of this family in the Edenian and Maysvillian. Two species which do not range above the O. velicuspis Zone (Sweet, 1979, 1984), Culumbodina occidentalis and Panderodus breviusculis Barnes, range to within $8 \mathrm{~m}$ of the top of the formation at Bessels Fjord. The top of the formation is either of $O$. velicuspis Zone or earliest $O$. robustus Zone age. 


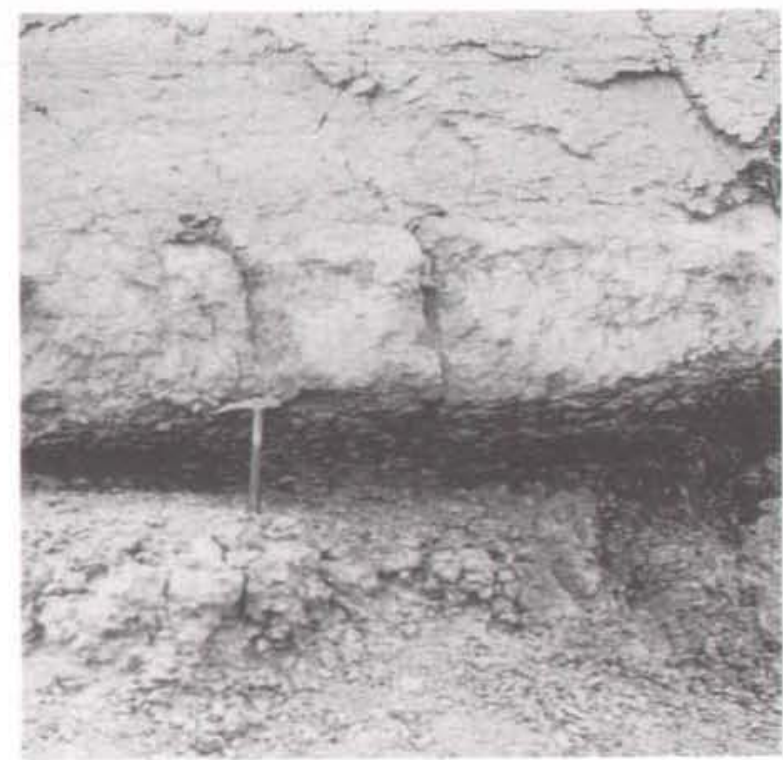

Fig. 7. Boundary between the Cape Calhoun and Aleqatsiaq Fjord Formations (marked by hammer) in the reference section for the Cape Calhoun Formation in southern Bessels Fjord (MPS 840813-1, see fig. 4).

Boundaries. The lower boundary is taken at the distinctive change to pale green colouration. The upper boundary is more gradational since green partings persist into the lower few metres of massively weathering limestones. The boundary is placed at the top of a deeply recessive, shaly micrite which varies in thickness from a few centimetres at most localities to $10 \mathrm{~cm}$ at Bessels Fjord, where it forms a distinctive black line in the cliffs (fig. 7).

Distribution. The formation is an easily identifiable marker and mapping horizon extending from Morris Bugt in the west to Nordenskiöld Fjord in the east (figs $1,3)$.

\section{Aleqatsiaq Fjord Formation}

History. The formation was erected by Peel \& Hurst (1980) and has a complex terminological history (cf. Hurst, 1980; Sønderholm \& Harland, in prep.). It corresponds to units $1 \mathrm{~A}-\mathrm{C}$, units $13 \mathrm{~B}-\mathrm{C}$ and unit $14 \mathrm{~B}$ of Dawes \& Peel (1984), and to units AF1-3 of Sønderholm et al. (1987).

Name. From Aleqatsiaq Fjord on the north-western coast of Washington Land. On old maps it is referred to as Alakratiak Fjord.
Type section. The type section is on the south-western slopes of Pentamerus Bjerge, on the east side of the north-south valley extending from the head of the fjord (fig. 1).

Thickness. Sønderholm \& Harland (in prep.) report thicknesses between $250 \mathrm{~m}$ and $360 \mathrm{~m}$.

Lithology. The formation generally comprises dark grey-brown weathering dolomitic wackestone and packstone with a distinctive nodular and burrow-mottled appearance. In contrast, the middle member is composed of massive, pale weathering, grey to dark grey, slightly mottled dolomitic limestones. In the area between Bessels Fjord and Newman Bugt, small mounds occur within the middle member (Sønderholm \& Harland, 1989, in prep.). The lithology of the unit is fully described in Sønderholm \& Harland (in prep.).

Biota and age. The formation is richly fossiliferous with a diverse shelly fauna associated with graptolites and various forms of dasycladacean algae (Troedsson, 1926, 1928; Dawes \& Peel, 1984; Sønderholm \& Harland, in prep.). The Ordovician index gastropod Maclurites is present in the lower part of the formation and there are early Aeronian (Llandovery) trilobites and pentamerid brachiopods in the upper part (Lane, 1979). Palynomorphs are common (Nøhr-Hansen, 1989; Grahn \& Nøhr-Hansen, 1989).

Species of Aphelognathus are almost completely absent from the conodont faunas and this makes the recognition difficult of zones younger than the $O$. robustus Zone (Sweet, 1984). At Aleqatsiaq Fjord, Ordovician conodonts including Pseudobelodina? dispansa (Glenister) are present up to $276 \mathrm{~m}$ above the base of the formation. More precise information is available at Kap Ammen, Nyeboe Land, where P? dispansa, Paroistodus? mutatus (Branson \& Mehl), Pseudobelodina vulgaris vulgaris Sweet, Walliserodus amplissimus (Serpagli), a species close to Aphelognathus divergens Sweet and Oulodus robustus (Branson, Mehl \& Branson) occur at the base of the Kap Ammen Member. All of these species are restricted to the Ordovician (Sweet, 1984). Conodont faunas higher in the member are very sparse but the presence of the Silurian genus Distomodus $1 \mathrm{~m}$ below the top of the Kap Ammen Member indicates that the Ordovician-Silurian boundary falls within it and this is supported by the presence of the cephalopod Huronia and the brachiopod Holorhyncus (Dawes \& Peel, 1984). The overlying Store Canyon Member contains thick-shelled pentamerid brachiopods, including Virgiana, of early Silurian age (Sønderholm et al., 1987). 
Boundaries. In the area between Morris Bugt and Nordenskiöld Fjord, the Aleqatsiaq Fjord Formation conformably overlies the Cape Calhoun Formation. The latter wedges out east of Nordenskiöld Fjord and the Aleqatsiaq Fjord Formation directly overlies the Kap Jackson Formation.

The Aleqatsiaq Fjord Formation is laterally equivalent to the upper member of the Børglum River Formation and the Turesø Formation. The junction of the two stratigraphic schemes lies under Hans Tavsen Iskappe.

In north-western Washington Land the formation is conformably overlain by the Cape Schuchert Formation (Peary Land Group) as defined by Hurst (1980). The boundary is taken at the change from light coloured lime wackestone to massive black, bituminous and cherty limestones and shales (Hurst, 1980). Outside this area, the Aleqatsiaq Fjord Formation is conformably overlain by the Washington Land Group (Hurst, 1980; Sønderholm et al., 1987). The boundary changes slightly in character from west to east. In the Washington Land - Hall Land region it is sharply defined by the change from dark to pale carbonates (Hurst, 1980; Sønderholm \& Harland, in prep.). Further to the east, the boundary is more transitional, since the bottom of the Washington Land Group weathers darker. The boundary is then chosen at the change from relatively recessive, mediumbedded, pentameroid-rich, dark limestones to massive, cliff-forming dark biostromal limestones with few pentameroids. In the Freuchen Land - J. P. Koch Fjord area the base of the overlying unit weathers pale, but is recessive and often poorly exposed.

Distribution. The formation crops out between Morris Bugt, Washington Land, and the western side of Hans Tavsen Iskappe in westernmost Peary Land.

Subdivision. The Aleqatsiaq Fjord Formation is divided into three members, the Newman Bugt $(110-170 \mathrm{~m})$, Kap Ammen $(40-85 \mathrm{~m})$ and Store Canyon Members (60-113 m) (Sønderholm \& Harland, in prep.).

\section{Borglum River Formation}

History. The Børglum River Formation of current usage was defined by Christie \& Peel (1977) who revised the earlier definitions of Troelsen (1949) and Mayr (1976). It corresponds in part to the dark weathering limestone and dolomite unit' of Christie \& Ineson (1979) in the area around G. B. Schley Fjord. In Kronprins Christian Land, the embracive Centrum Limestone of Adams \& Cowie (1953) included strata now assigned to the Børg- lum River Formation. Scrutton (1975) used a different concept for this unit which probably equates approximately to the Børglum River Formation of present usage (Peel, 1980; Peel et al., 1981; Peel, 1982). Neither Adams \& Cowie nor Scrutton recognised the effects of widespread thrusting within the strata which, together with a lack of precision regarding definition and content of the units, led Peel et al. (1981) to abandon these terms. The Børglum River Formation was subdivided into three informal members by Christie \& Peel (1977); the 'lower limestone member' $(260 \mathrm{~m})$, the 'middle limestone and dolomite member' (c. $40 \mathrm{~m}$ ) and the 'úpper limestone member' $(130 \mathrm{~m})$.

Name. After the river, Børglum Elv in central Peary Land.

Type section. The type section is at Børglum Elv (fig. 1).

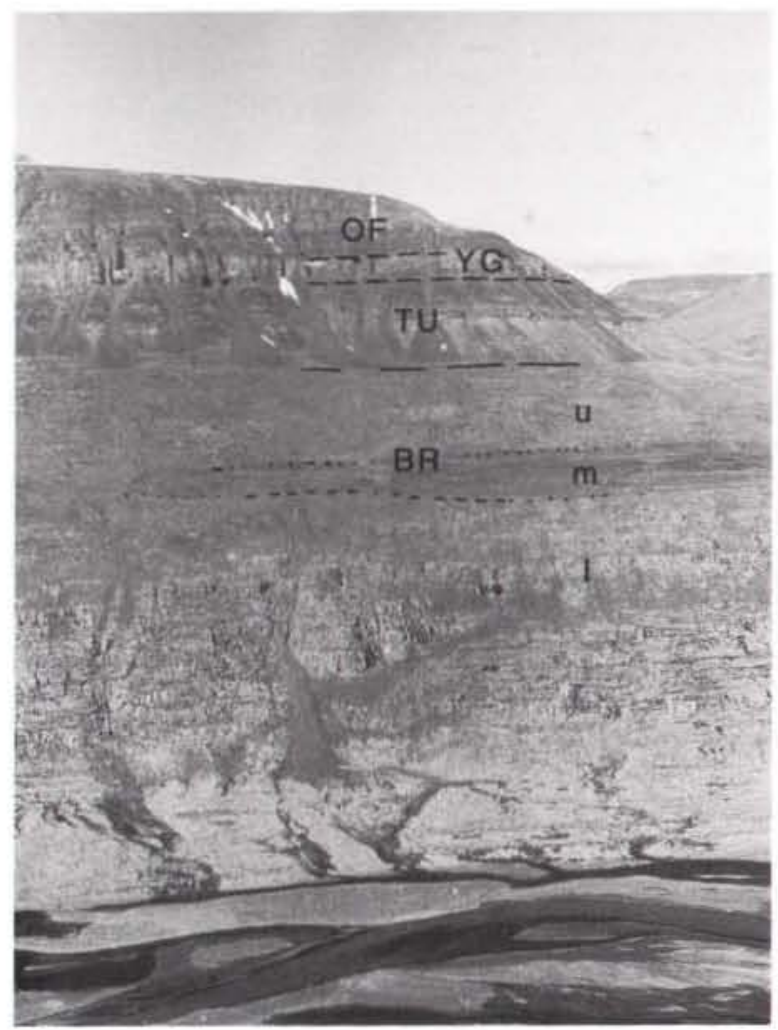

Fig. 8. Morris Bugt Group (BR: Børglum River; TU: Turesø Formations) as exposed at Børglum Elv, central Peary Land. The informal lower, middle and upper members of the BørgIum River Formation are indicated by I, m, u, respectively. The Turess Formation is overlain by the Ymers Gletscher (YG) and Odins Fjord Formations (OF). Thickness of Turess Formation is approximately $150 \mathrm{~m}$. The boundary between the Børglum River and Wandel Valley Formations in the bottom of the valley is obscured by drift. 
Thickness. In the type section the formation is $430 \mathrm{~m}$ thick. In Kronprins Christian Land the formation may be substantially thicker, but the effects of repetition by thrusting in the stratigraphically monotonous unit have not yet been fully assessed (Peel, 1985).

Lithology. The lower $260 \mathrm{~m}$ and upper $130 \mathrm{~m}$ of the Børglum River Formation consist of medium- to thickbedded, dark brown to yellowish-grey weathering, conspicuously burrow-mottled, dolomitic, nodular, pelletal lime mudstone, skeletal wackestone and packstone. Between these, a $40 \mathrm{~m}$ thick, unfossiliferous unit occurs, comprising dark weathering, thinly interbedded pelletal limy dolomite and lime mudstone, in places with abundant chert nodules (fig. 8).

Biota and age. The formation has a rich benthic epifauna and infauna, although it is not fully described (Troelsen, 1949; Christie \& Peel, 1977; Frykman, 1979a; Hurst \& Surlyk, 1983; Peel, 1985). The general aspect of the macrofauna suggests a Middle Ordovician to early Late Ordovician age.

Conodont faunas are sparse throughout the formation, with the exception of the middle member and lowest part of the upper member. The basal beds of the formation are of low diversity, but those species which are present, including a new species of Oulodus, also occur at the base of the Kap Jackson Formation, and there is no evidence for diachronism.

The first occurrence of Pseudobelodina vulgaris vulgaris Sweet at $13 \mathrm{~m}$ in the informal middle member and Panderodus breviusculus Barnes at the base of the upper member in Børglum Elv indicates that this interval may be referred to the $O$. velicuspis Zone and correlates with the upper part of the Kap Jackson Formation and the Cape Calhoun Formation. Faunas from the uppermost part of the formation contain only Drepanoistodus suberectus (Branson \& Mehl) and species of Panderodus with no zonally diagnostic taxa present. The base of the overlying Turesø Formation does, however, contain latest Richmondian (Late Ordovician) conodont faunas (Armstrong, 1983, in press).

Boundaries. The lower boundary to the Ryder Gletscher Group is conformable and marked by a change from recessive, grey weathering dolomites to dark, cliff-forming limestones (fig. 9). In Børglum Elv an approximately $15 \mathrm{~m}$ thick transitional, grey weathering, medium-bedded limestone unit occurs at the base of the Børglum River Formation (see also Kap Jackson Formation). The upper boundary to the Turesø Formation is taken at the incoming of the first dolomitic or limy dolomitic bed which is accompanied by a change to

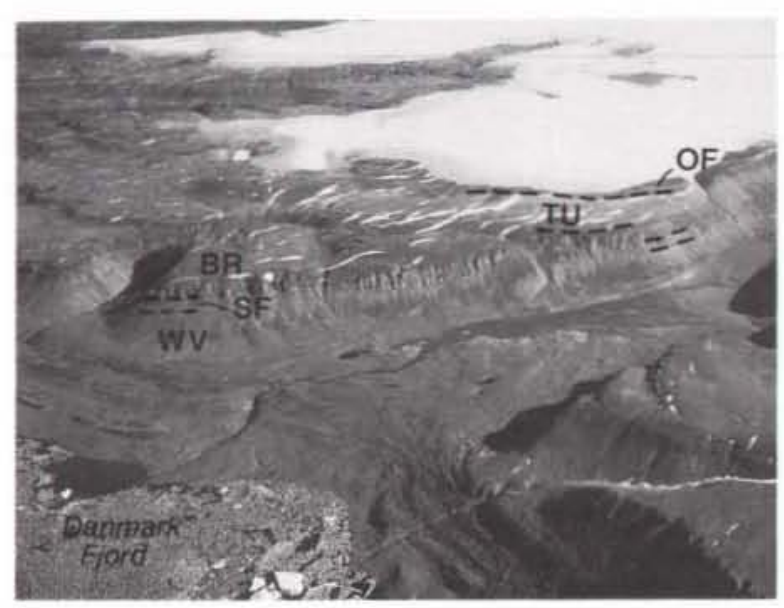

Fig. 9. Morris Bugt Group (BR: Børglum River Formation and TU: Turesø Formation) of Kronprins Christian Land on the eastern coast of Danmark Fjord. WV: Wandel Valley Formation, SF: Sjalland Fjelde Formation and OF: Odins Fjord Formation. Base of ice-cap is approximately $700 \mathrm{~m}$. Aerial photograph 664 A-Ø, no. 12 354. Copyright Kort- og Matrikelstyrelsen, Denmark (A. 200/87).

pale coloured, well-laminated and recessive weathering beds (figs 8,9 ).

Distribution. The Børglum River Formation can be followed as a mainly cliff-forming, dark weathering unit from the eastern side of Hans Tavsen Iskappe across Peary Land to Valdemar Glückstadt Land (fig. 8). Isolated outcrops occur in the G. B. Schley Fjord region. In Kronprins Christian Land the formation is exposed in a series of north-south trending thrust sheets (fig. 1) (Christie \& Peel, 1977; Peel, 1980).

\section{Tures 9 Formation}

History. The formation was erected by Hurst (1984) who reviewed the history of the unit.

Name. From the lake, Turesø, south of Odin Fjord, Peary Land.

Type section. The type section is on the western side of Turesø (figs 1, 10).

Thickness. The formation is between 115 and $150 \mathrm{~m}$ in Peary Land, but it is possibly up to $200 \mathrm{~m}$ thick in Kronprins Christian Land (Peel, 1980; Hurst, 1984).

Lithology. The Turesø Formation is a dark and light grey banded unit, characterised by medium- to thickbedded dolomite and limy dolomite. The upper half of 


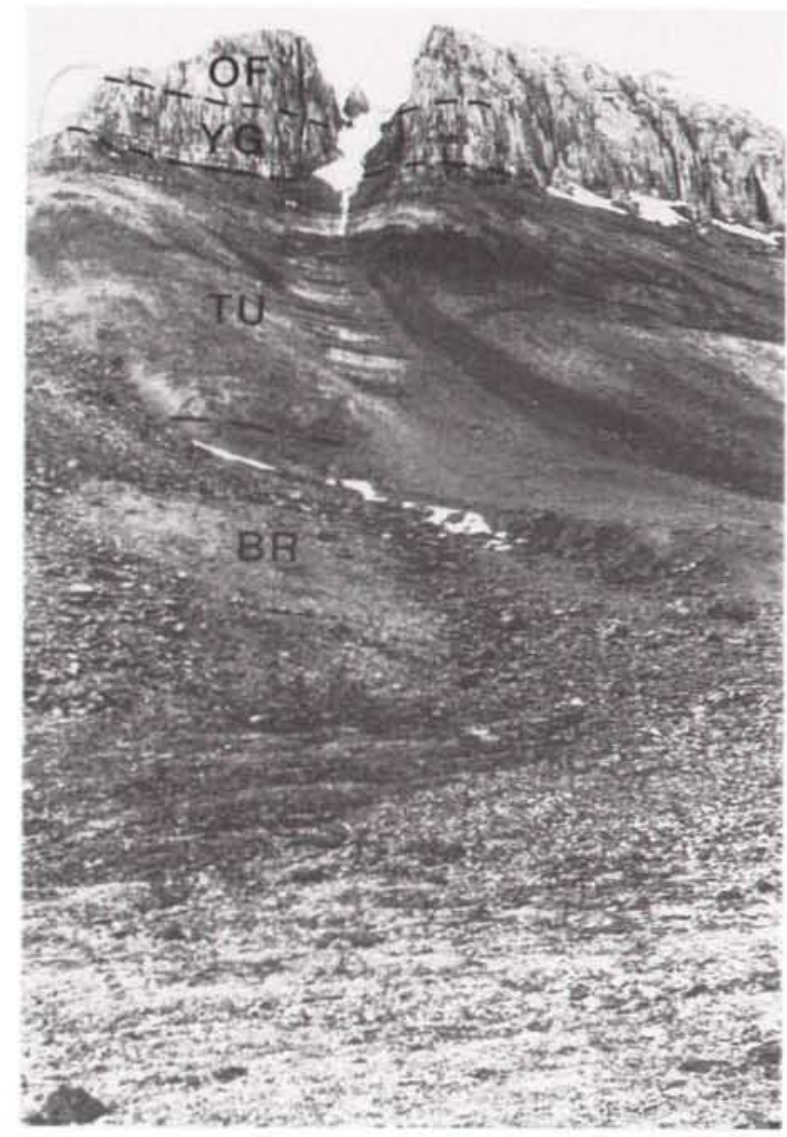

Fig. 10. Type section of the Turesø Formation (TU) at Turesø, central Peary Land. BR: Børglum River Formation; OF: Odins Fjord Formation; YG: Ymers Gletscher Formation. The thickness of the Turesø Formation is $145 \mathrm{~m}$.

the formation weathers darker than the lower half. The dolomitic beds are generally grey weathering, commonly massive and often pervasively burrow-mottled. Rounded to irregular calcite-filled vugs are often developed, and traces of irregular laminae, reminiscent of cryptalgalaminite, may be present. The limy dolomitic beds weather dark grey and mostly consist of nodular pelletal and skeletal wackestone, but distinct horizons up to $10 \mathrm{~m}$ thick of fenestral lime mudstone or cryptalgalaminites occur. The fauna is very poor in the lower half of the formation, yielding only rare cephalopods and gastropods. Brachiopod coquinas occur in the upper half of the formation.

Sediments referable to this formation in the G. B. Schley Fjord region in eastern Peary Land and in Kronprins Christian Land are less dolomitic and have a higher proportion of nodular lime wackestone than cryptalgalaminite. Coquinas are more common and the faunal density and diversity is greater.
Shelf rim facies of the Tures $ø$ Formation have been recorded from carbonate boulder conglomerates within the Citronens Fjord Member of the Merqujôq Formation (Hurst \& Surlyk, 1982; Hurst, 1984). The boulders consist of lithoclastic-bioclastic grainstones rich in fragments of virgianid brachiopods, stromatoporoids, gastropods, and recrystallised algae. Some dolomite clasts are stained red suggesting the presence of high energy carbonate sand shoals which may have been subjected to subaerial exposure. The abundance of algae may suggest the presence of algal reefs (Hurst, 1984).

Boundaries. The lower boundary is taken at the lowest occurrence of dolomitic or limy dolomitic beds which is generally accompanied by a substantial decline in faunal density and diversity. The Turesø Formation is conformably overlain by the Ymers Gletscher Formation in Peary Land, except in the G. B. Schley Fjord region, where the latter has not been recognised (Hurst, 1984). The boundary is normally sharp since the Ymers Gletscher Formation is a pale, well-laminated and recessive unit, in contrast to the darker, more massive upper part of the Turesø Formation (figs 8, 10).

The Ymers Gletscher Formation has not been recognised with certainty outside Peary Land (Hurst, 1984). In Kronprins Christian Land it may form the upper part of the 'un-named Silurian(?) dolomite formation' of Peel (1980) which, however, was assigned to the Turesø Formation as a whole by Hurst (1984). Hence, the Turesø Formation is conformably overlain by the Odins Fjord Formation in Valdemar Glückstadt Land and Kronpris Christian Land (figs 2, 9). The upper boundary of the Turesø Formation in these areas is taken at the first incoming of massive, mottled, dark grey skeletal lime wackestone of the Odins Fjord Formation (Hurst, 1984).

Distribution. The formation outcrops as a relatively cliff-forming, striped unit in a belt from the eastern side of Hans Tavsen Iskappe and eastwards across Peary Land to Valdemar Glückstadt Land (fig. 10). Isolated outcrops occur around G. B. Schley Fjord (fig. 1). In Kronprins Christian Land the formation is repeated in a series of north-south trending thrust sheets (Hurst, 1984; Hurst et al., 1985).

Biota and age. The macrofauna in the lower half of the formation includes macluritid gastropods, indicating a general Ordovician age for this part, and actinoceratid cephalopods. The upper half contains smooth virgianid brachiopods, suggesting an early to middle Llandovery (Silurian) age (Fürsich \& Hurst, 1980; Armstrong \& Lane, 1981; Hurst, 1984). 
The conodonts Rhipidognathus symmetricus (Branson, Mehl \& Branson) and Aphelognathus pyramidalis (Branson, Mehl \& Branson) are present up to $40 \mathrm{~m}$ above the formation base in Børglum Elv indicating an Ordovician age (Armstrong, 1983, in press). Typical Silurian taxa, including Ozarkodina hassi (Pollock et al.) and Ozarkodina excavata (Branson \& Mehl) have their first appearance $20 \mathrm{~m}$ higher in the section.

\section{Correlation with Arctic Canada, East Greenland and Svalbard}

In the Canadian Arctic Archipelago, the lithostratigraphic equivalents of the Kap Jackson, Cape Calhoun and Aleqatsiaq Fjord Formations are, respectively, the Thumb Mountain, Irene Bay and Allen Bay Formations (Peel \& Christie, 1982) (fig. 11). Conodonts from the Canadian units have been described by Nowlan (1976) and the faunas were listed by Thorsteinsson \& Mayr (1987). The base of the Thumb Mountain Formation contains a similar, though less diverse, assemblage to that at the base of the Kap Jackson Formation and no diachronism is indicated.
Conodonts from the Irene Bay Formation have traditionally been interpreted as being of mid- to late Maysvillian age (Barnes et al., 1976, 1981; Nowlan, 1976). However, the characteristic $O$. velicuspis Zone assemblage first appears just below the Thumb Mountain Irene Bay boundary, in close comparison with the first appearance below the Cape Calhoun Formation. The zone ranges from mid-Edenian to mid-Maysvillian (Sweet, 1984) and the Cape Calhoun Formation is largely contained within it. The respective conodont faunas indicate a similar mid- to late Edenian age for the base of the two units. There is some evidence to indicate that the top of the Irene Bay Formation may be slightly younger than its Greenland counterpart; the characteristic species Culumbodina occidentalis Sweet and $C$. penna Sweet both have last appearances relatively lower in the Irene Bay Formation than in the Cape Calhoun Formation (fig. 11).

The Allen Bay Formation was divided into three informal members by Thorsteinsson \& Mayr (1987). The lower member, up to $145 \mathrm{~m}$ thick, is of similar lithology to the Newman Bugt Member, a correlation supported by the presence of Maclurites and a poorly diagnostic conodont fauna of Richmondian age. The middle mem-

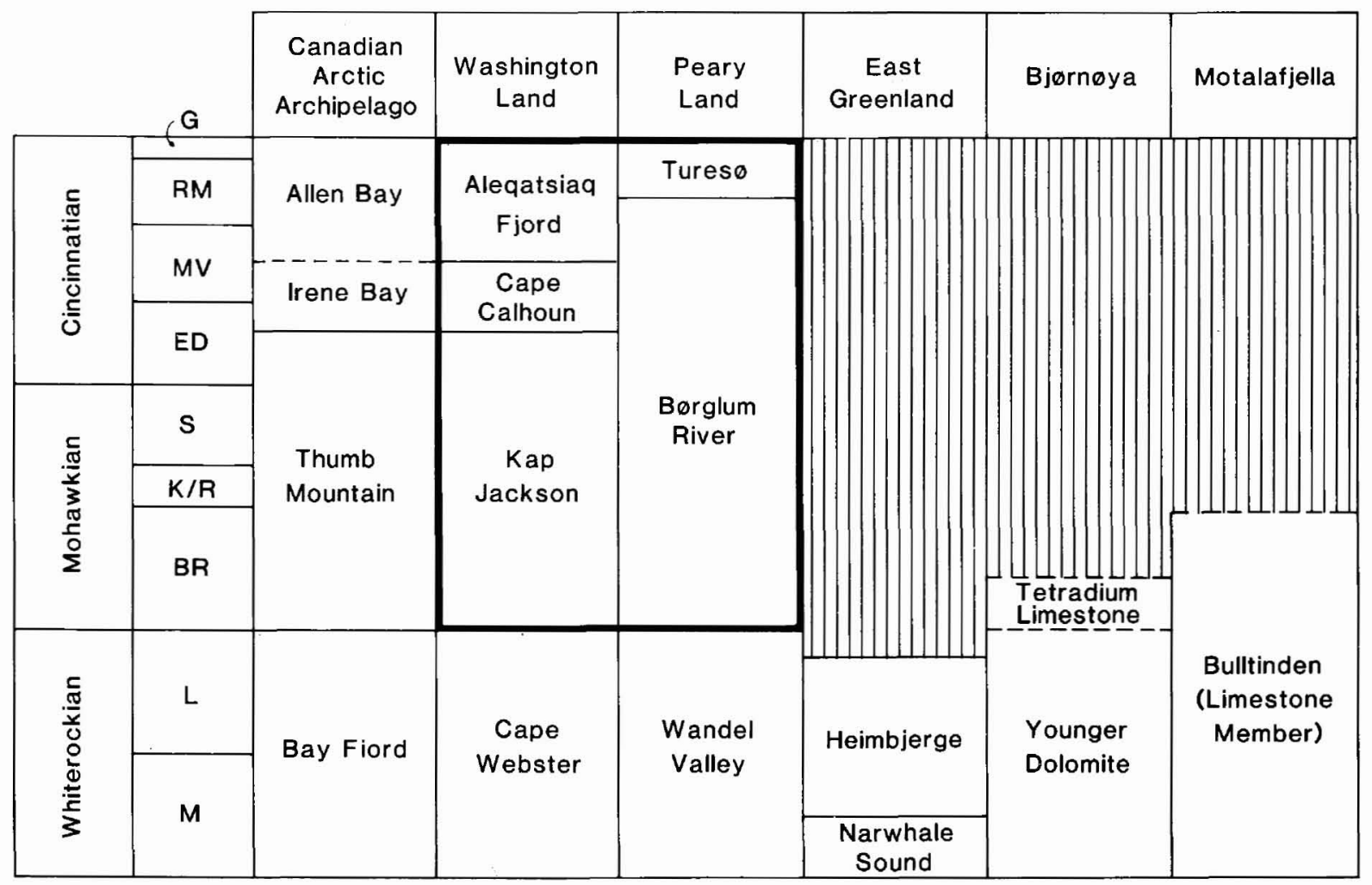

Fig. 11. Correlation chart of the Ordovician part of the Morris Bugt Group (framed) with units in the Canadian Arctic Archipelago, East Greenland and Svalbard. Series abbrevations as for fig. 2. 
ber is $300 \mathrm{~m}$ thick and may overlie the lower member with slight unconformity (Thorsteinsson \& Mayr, 1987). Kockelella manitoulinensis Pollock et al. is present at the base of the middle member, a species that Armstrong $(1983$, in press) reported from the upper half of the Turesø Formation. The member is otherwise poorly dated but the lower part is probably equivalent to the upper part of the Kap Ammen Member and the Store Canyon Member. The top of the Allen Bay Formation is no older than $O$. crassa Zone (early Ludlow) (Thorsteinsson \& Mayr, 1987), indicating that the upper part of the formation is equivalent to the Washington Land Group rather than the Morris Bugt Group.

In East Greenland, the youngest Lower Palaeozoic unit, the Heimbjerge Formation, is older than the Morris Bugt Group (fig. 11). On Albert Heim Bjerge, at the type locality, the conodont faunas indicate that the formation extends into the $P$. friendsvillensis Zone of Late Whiterockian age (Smith, 1982, 1985). Some $15 \mathrm{~km}$ to the north on C. H. Ostenfeld Nunatak an additional 600 $\mathrm{m}$ of sediment is preserved at the top of the unit (Frykman, 1979b) but does not extend above the $P$. sweet Zone; it is thus contained within the Late Whiterockian (Smith, 1982, 1985).

The Lower Palaeozoic sequences of Svalbard are principally restricted to the Cambrian and Lower Ordovician. At only two localities, Bjørnøya and Motalafjella, have younger Ordovician sediments been proven (fig. 11). On Bjørnøya, the Tetradium Limestone has long been recognised as being of Middle Ordovician age (Holtedahl, 1920; Horn \& Orvin, 1927). Lithologically the unit comprises dark grey lime mudstones of similar appearance to the lower part of the Morris Bugt Group. It too overlies algal-laminated, peritidal dolomites, lithologically comparable to the Wandel Valley Formation of Peary Land (Peel \& Smith, 1988). The macrofauna of the Tetradium Limestone is in need of revision but includes Tetradium, Rafinesquina, Gonioceras and Actinoceras (Holtedahl, 1920), all of which are present at the base of the Morris Bugt Group (Troedsson, 1926, 1928). Conodont faunas from the lower part of the unit (Smith, unpublished collections) are also closely similar to those at the base of the Morris Bugt Group. Further work on the Bjørnøya faunas is needed, but the base of the Tetradium Limestone is probably closely similar in age to that of the Morris Bugt Group.

It has only recently been recognised that the Bulltinden Formation of Motalafjella, central western Spitsbergen, contains Ordovician sediments. Scrutton et al. (1976) had previously demonstrated the presence of Silurian faunas in the middle Boulder Conglomerate Member but more recent work (Armstrong et al., 1986) has recovered Ordovician conodonts from the under- lying Limestone Member. The conodonts are of North Atlantic provincial affinity but are poorly diagnostic, indicating a minimum age of early Caradoc (early Mohawkian) and a maximum age of late Arenig (Early Whiterockian).

Acknowledgments. We thank John S. Peel for free access to section data and for critically reading the manuscript. Ian D. Bryant, Poul H. Due, Tom L. Harland and Lars N. Jørgensen are thanked for assistance in the field. Bente Thomas and Susanne Hansen are thanked for technical assistance. SJT acknowledges the award of a NERC research studentship. Participation in the 1986 Cambridge Arctic Shelf Programme expedition to Svalbard allowed MPS to examine the Ordovician succession on Bjørnøya.

\section{References}

Adams, P. J. \& Cowie, J. W. 1953: A geological reconaissance of the region round the inner part of Danmark Fjord, Northeast Greenland. Meddr Grønland 111(7), 24 pp.

Armstrong, H. A. 1983: The early Silurian conodont micropalaeontology of the North Greenland carbonate platform. Unpublished Ph.D. thesis, University of Nottingham, England, $387 \mathrm{pp}$.

Armstrong, H. A. in press: Conodonts from the Upper Ordovician - Lower Silurian carbonate platform of North Greenland. Bull.Grønlands geol. Unders. 159.

Armstrong, H. A. \& Lane, P. D. 1981: The un-named Silurian(?) dolomite formation, Børglum Elv, central Peary Land. Rapp. Grønlands geol. Unders. 106, 29-34.

Armstrong, H. A., Nakrem, H. A. \& Ohta, Y. 1986: Ordovician conodonts from the Bulltinden Formation, Motalafjella, central-western Spitsbergen. Polar Res. 4, 17-23.

Barnes, C. R., Jackson, D. E. \& Norford, B. S. 1976: Correlation between Canadian Ordovician zonation based on graptolites, conodonts and benthic macrofossils from key successions. In Bassett, M. G. (edit.) The Ordovician System, 209-229. Cardiff: University of Wales Press and National Museum of Wales.

Barnes, C. R., Norford, B. S. \& Skevington, D. 1981: The Ordovician System in Canada. Publ. Int. Union geol. Sci. 8 , 27 pp.

Bergström, S. M. 1971: Conodont biostratigraphy of the Middle and Upper Ordovician of Europe and eastern North America. Mem. geol. Soc. Am. 127, 83-161.

Bergström, S. M. 1983: Biostratigraphy, evolutionary relationships, and biostratigraphic significance of Ordovician platform conodonts. Fossils \& Strata 15, 35-58.

Bergström, S. M., Carnes, J. B., Hall, J. C., Kurapkat, W. \& O’Neil, B. E. 1988: Conodont biostratigraphy of some Middle Ordovician stratotypes in the southern and central Appalachians. Bull. New York State Mus. 462, 20-32.

Christie, R. L. \& Ineson, J. R. 1979: Precambrian-Silurian 
geology of the G. B. Schley Fjord region, eastern Peary Land, North Greenland. Rapp. Grønlands geol. Unders. 88, 63-71.

Christie, R. L. \& Peel, J. S. 1977: Cambrian-Silurian stratigraphy of Børglum Elv, Peary Land, eastern North Greenland. Rapp. Gronlands geol. Unders. 82, 48 pp.

Dawes, P. R. \& Peel, J. S. 1984: Biostratigraphic reconnaissance in the Lower Palaeozoic of western North Greenland. Rapp. Grønlands geol. Unders. 121, 19-51.

Escher, J. C. \& Larsen, P.-H. 1987: The buried western extension of the Navarana Fjord escarpment in central and western North Greenland. Rapp. Grønlands geol. Unders. 133, 81-89.

Fortey, R. A. 1984: Global earlier Ordovician transgressions and regressions and their biological implications. In Bruton, D. L. (edit.) Aspects of the Ordovician System, 37-50. Oslo: Universitetsforlaget.

Frykman, P. 1979a: Ordovician chitinous hydroids from Peary Land, eastern North Greenland. Rapp. Gronlands geol. Unders. 91, 25-27.

Frykman, P. 1979b: Cambro-Ordovician rocks of C. H. Ostenfeld Nunatak, northern East Greenland. Rapp. Grønlands geol. Unders. 91, 125-132.

Fürsich, F. T. \& Hurst, J. M. 1980: Euryhalinity of Palaeozoic articulate brachiopods. Lethaia 13, 303-312.

Grahn, Y. \& Nøhr-Hansen, H. 1989: Chitinozoans from Ordovician and Silurian shelf and slope sequences in North Greenland. Rapp. Grønlands geol. Unders. 144, 35-41.

Higgins, A. K., Ineson, J. R., Peel, J. S., Surlyk, F. \& Sønderholm, M. in press: Cambrian to Silurian basin development and sedimentation, North Greenland. In Trettin, H. P. (edit.) The Innuitian region. The geology of North America, vol. E. Ottawa: Geological Survey of Canada.

Holtedahl, O. 1920: On the Paleozoic series of Bear Island, especially on the Heclahook System. Norsk Geol. Tidsskr. 5, 121-148.

Horn, G. \& Orvin, A. K. 1927: Geology of Bear Island. Skr. Svalbard Ishavet 15, $152 \mathrm{pp}$.

Hurst, J. M. 1980: Silurian stratigraphy and facies distribution in Washington Land and western Hall Land, North Greenland. Bull. Gronlands geol. Unders. 138, $95 \mathrm{pp}$.

Hurst, J. M. 1984: Upper Ordovician and Silurian carbonate shelf stratigraphy, facies and evolution, eastern North Greenland. Bull. Grønlands geol. Unders. 148, 73 pp.

Hurst, J. M. \& Peel, J. S. 1979: Late Proterozoic(?) to Silurian stratigraphy of southern Wulff Land, North Greenland. Rapp. Grønlands geol. Unders. 91, 37-56.

Hurst, J. M. \& Surlyk, F. 1982: Stratigraphy of the Silurian turbidite sequence of North Greenland. Bull. Grønlands geol. Unders. 145, $121 \mathrm{pp}$.

Hurst, J. M. \& Surlyk, F. 1983: Initiation, evolution, and destruction of an early Paleozoic carbonate shelf, eastern North Greenland. J. Geol. 91, 671-691.

Hurst, J. M., Jepsen, H. F., Kalsbek, F., McKerrow, W. S. \& Peel, J. S. 1985: The geology of the northern extremity of the East Greenland Caledonides. In Gee, D. G. \& Sturt, B. A. (edit.) The Caledonide orogen - Scandinavia and related areas, 1047-1063. John Wiley \& Sons Ltd.
Ineson, J. R., Peel, J. S. \& Smith, M. P. 1986: The Sjælland Fjelde Formation: a new Ordovician formation from eastern North Greenland. Rapp. Grønlands geol. Unders. 132, 27-37.

Koch, L. 1929a: Stratigraphy of Greenland. Meddr Grønland 73(2), 2, 205-320.

Koch, L. 1929b: The geology of the south coast of Washington Land. Meddr Gronland 73(1), 1, 39pp.

Lane, P. D. 1979: Llandovery trilobites form Washington Land, North Greenland. Bull. Grønlands geol. Unders. 131, 37 pp.

Mayr, U. 1976: Middle Silurian reefs in southern Peary Land, North Greenland. Bull. Can. Petr. Geol. 24, 440-449.

Nøhr-Hansen, H. 1989: Palynological studies of the organic matter. In Christiansen, F. G. (edit.) Petroleum geology of North Greenland. Bull. Grønlands geol. Unders. 158, 27-31.

Nøhr-Hansen, H. \& Koppelhus, E. B. 1988: Ordovician spores with trilete rays, from Washington Land, North Greenland. Rev. Palaeobot. Palynol. 56, 305-311.

Nowlan, G. S. 1976: Late Cambrian to Late Ordovician conodont evolution and biostratigraphy of the Franklinian Miogeosyncline, eastern Canadian Arctic Islands. Unpublished Ph.D. thesis, University of Waterloo, Ontario, $590 \mathrm{pp}$.

Paul, C. R. C. 1979: The cystoid Pleurocystites (Echinodermata) from the Ordovician of North Greenland. Rapp. Grønlands geol. Unders. 91, 83-86.

Peel, J. S. 1980: Geological reconnaissance in the Caledonian foreland of eastern North Greenland with comments on the Centrum Limestone. Rapp. Grønlands geol. Unders. 99, 61-72.

Peel, J. S. 1982: The Lower Paleozoic of Greenland. In Embry, A. F. \& Balkwill, H. R. (edit.) Arctic geology and geophysics. Mem. Can. Soc. Petrol. Geol. 8, 309-330.

Peel, J. S. 1985: Cambrian-Silurian platform stratigraphy of eastern North Greenland. In Gee, D. G. \& Sturt, B. A. (edit.) The Caledonide Orogen - Scandinavia and related areas, 1077-1094. John Wiley \& Sons Ltd.

Peel, J. S. \& Christie, R. L. 1982: Cambrian-Ordovician platform stratigraphy: correlations around Kane Basin. In Dawes, P. R. \& Kerr, J. W. (edit.) Nares Strait and the drift of Greenland: a conflict in plate tectonics. Meddr Grønland Geosci. 8, 117-135.

Peel, J. S. \& Hurst, J. M. 1980: Late Ordovician and early Silurian stratigraphy of Washington Land, western North Greenland. Rapp. Grønlands geol. Unders. 100, 18-24.

Peel, J. S., Ineson, J. R., Lane, P. D. \& Armstrong, H. A. 1981: Lower Palaeozoic stratigraphy around Danmarks Fjord, eastern North Greenland. Rapp. Grønlands geol. Unders. 106, 21-27.

Peel, J. S. \& Smith, M. P. 1988: The Wandel Valley Formation (Early - Middle Ordovician) of North Greenland and its correlatives. Rapp. Gronlands geol. Unders. 137, 61-92.

Scrutton, C. T. 1975: Corals and stromatoporoids from the Ordovician and Silurian of Kronprins Christian Land, Northeast Greenland. Meddr Grønland 171(4), 43 pp.

Scrutton, C. T., Horsfield, W. T. \& Harland, W. B. 1976: Silurian fossils from western Spitsbergen. Geol. Mag. 113, 519-523. 
Smith, M. P. 1982: Conodonts from the Ordovician of East Greenland. Rapp. Grønlands geol. Unders. 108, 14 only.

Smith, M. P. 1985: Ibexian-Whiterockian (Ordovician) conodont palaeontology of East and eastern North Greenland. Unpublished Ph.D. thesis, University of Nottingham, England, $372 \mathrm{pp}$.

Sønderholm, M. \& Due, P. H. 1985: Lower and Middle Ordovician platform carbonate lithostratigraphy of Warming Land, Wulff Land and Nares Land, North Greenland. Rapp. Grønlands geol. Unders. 126, 31-46.

Sønderholm, M. \& Harland, T. L. 1989: Latest Ordovician earliest Silurian reef mounds in western North Greenland. In Geldsetzer, H. J. J., James, N. P. \& Tebbutt, G. E. (edit.) Reefs - Canada and adjacent areas. Mem. Can. Soc. Petrol. Geol. 13, 241-243.

Sønderholm, M. \& Harland, T. L. in prep.: The Late Ordovician - Silurian carbonate shelf in North Greenland: depositional evolution and lithostratigraphy of the upper Morris Bugt Group and the Washington Land Group. Manuscript Grønlands geologiske Undersøgelse.

Sønderholm, M., Harland, T. L., Due, P. H., Jørgensen, L. N. \& Peel, J. S. 1987: Lithostratigraphy and depositional history of Upper Ordovician - Silurian shelf carbonates in central and western North Greenland. Rapp. Gronlands geol. Unders. 133, 27-40.

Surlyk, F., Hurst, J. M. \& Bjerreskov, M. 1980: First agediagnostic fossils from the central part of the North Greenland fold belt. Nature 286, 800-803.

Sweet, W. C. 1979: Late Ordovician conodonts and biostratigraphy of the western Midcontinent Province. Geol. Stud. Brigham Young Univ. 26(3), 45-85.
Sweet, W. C. 1984: Graphic correlation of upper Middle and Upper Ordovician rocks, North American Midcontinent Province, USA. In Bruton, D. L. (edit.) Aspects of the Ordovician System, 23-35. Oslo: Universitetsforlaget.

Sweet, W. C. \& Bergström, S. M. 1984: Conodont provinces and biofacies of the Late Ordovician. Spec. Pap. geol. Soc. Am. 196, 69-87.

Teichert, C. 1937: A new Ordovician fauna from Washington Land, North Greenland. Meddr Grønland 119(1), 65 pp.

Thorsteinsson, R. \& Mayr, U. 1987: The sedimentary rocks of Devon Island, Canadian Archipelago. Mem. geol. Surv. Canada 411, 182 pp.

Troedsson, G. T. 1926: On the Middle and Upper Ordovician faunas of northern Greenland. I. Cephalopods. Meddr Grønland 71(1), $157 \mathrm{pp}$.

Troeddson, G. T. 1928: On the Middle and Upper Ordovician faunas of northern Greenland. II. Meddr Grønland 72(1), 1, 197 pp.

Troelsen, J. C. 1949: Contributions to the geology of the area around Jørgen Brønlund Fjord, Peary Land, North Greenland. Meddr Grønland 149(2), 1-29 pp.

Troelsen, J. C. 1950: Contributions to the geology of Northwest Greenland, Ellesmere Island and Axel Heiberg Island. Meddr Grønland 149(7), 86 pp.

Tull, S. J. 1988: Conodont micropalaeontology of the Morris Bugt Group (Middle Ordovician - Early Silurian), North Greenland. Unpublished Ph.D. thesis. Nottingham University, England, $366 \mathrm{pp}$. 